\title{
A NEW SPECIMEN OF ARAUCARIA FRICII FROM THE EARLY CONIACIAN OF THE BOHEMIAN MASSIF, CENTRAL EUROPE
}

\author{
JIŘÍ KVAČEK \\ National Museum, Prague, Václavské náměstí 68, 11000 Praha 1, the Czech Republic; e-mail: jiri.kvacek@nm.cz.
}

Kvaček, J. (2021): A new specimen of Araucaria fricii from the early Coniacian of the Bohemian Massif, Central Europe. Fossil Imprint, 77(2): 282-286, Praha. ISSN 2533-4050 (print), ISSN 2533-4069 (on-line).

\begin{abstract}
A specimen of Araucaria fricii is described from the upper part of the Teplice Formation in the Bohemian Cretaceous Basin. It extends the first occurrence of $A$. fricii from the mid-Coniacian back to the early Coniacian. Found in the Radovesice locality near Kučlín in the northern part of the Czech Republic, it is characterised by a deltoid cone scale complex with a centrally placed seed. It is compared to the type material of $A$. fricii from the mid-Coniacian Březno Formation and other European Cretaceous species of Araucaria. The taphonomy and palaeoecology of A. fricii is briefly discussed.
\end{abstract}

Key words: conifers, Araucariaceae, Araucaria, Cretaceous, Coniacian

Received: September 16, 2021 |Accepted: December 8, 2021| Issued: December 24, 2021

\section{Introduction}

The genus Araucaria Juss. is currently considered a typical representative of the Southern Hemisphere flora (Kunzmann 2007a), but this was not always the case. In the past, Araucariaceae, including the genus Araucaria, were quite common elements of the European Jurassic and Cretaceous floras. Their gradual decline is particularly noticeable in the Late Cretaceous (Stockey 1994, Kunzmann 2007a, Kvaček et al. 2019). By the Cenozoic, they had vanished from Europe; their rare occurrence in the Northern Hemisphere during the Tertiary was confined to East Asia (Oskolski 2015), as it is today.

Unequivocal finds of Araucaria from the European Late Cretaceous are rare (van der Ham et al. 2010). One of the historically earliest specimens (found in 1864) comes from the mid-Coniacian of the Bohemian Cretaceous Basin, described as Araucaria fricii VELEN. ex E.BAYER. A complete ovuliferous cone of $A$. fricii was later described from the Santonian of Belgium (Kunzmann 2007b). Sterile foliage of possible araucarian origin Brachyphyllum crassifolium (Corda) Bosma, van Konijnenb., van Amerom et HartK.FRÖD. from the Santonian of Swalmen near Aachen was described by Kräusel (1922) and later revised by Bosma et al. (2009). However, the latest report of Araucaria in Europe is by van der Ham (2004, van der Ham et al. 2010), from the late Maastrichtian of the Maastrichtian type area. The other Late Cretaceous species Araucaria bohemica VelEn. described from the Bohemian Cenomanian, was reinterpreted as the ovuliferous cone Alvinia J.KVAČEK of Frenelopsis alata (K.Feistm.) ERw.KnOBLoch (Kvaček 2000).
The Early Cretaceous record of the genus is represented by $A$. carolae L.KunZMANN from the Aptian/Albian of Nehden (Kunzmann 2007b). Other members of the Araucariaceae family from that period are recorded as pollen cone: Araucarites pedreranus BARALE and ovuliferous cone Dammarites coriaceae BARALE, both described from the Valanginian of Spain (Barale 1989, 1992). Pollen cones Rabagostrobus J.KvaČEK, E.BARrón, HeŘmanová et M.M.Mendes from the Early Cretaceous Aptian/Albian of Spain (Kvaček et al. 2018) and Callialastrobus J.KvAČEK et M.M.Mendes (Kvaček and Mendes 2020) from the Early Cretaceous of Portugal were recently described by the author and his co-workers.

Putative representatives of the family are reported from the European Cretaceous as sterile foliage Pagiophyllum brachyphyllum (E.BAYER) L.KUNZMANN from the midConiacian of the Bohemian Cretaceous (Kunzmann 2007b), P. pedreranum BARALE from the Valanginian of Spain (Barale 1989), Brachyphyllum obesum HeER from the Early Cretaceous of Portugal and Spain (Heer 1881, Saporta 1894, Kvaček et al. 2018), B. squamosum (Velen.) PALiB. from the Cenomanian to Santonian of the Czech Republic (Němejc and Kvaček 1975, Kvaček 2007), and B. patens (MiQ.) R.W.HAM et VAN KONIJNENB nom. illeg. (non Brachyphyllum patens (BRONGn.) SCHENK ex M.HÉBERT; Hébert 1869) from the Maastrichtian of the Netherlands (van der Ham et al. 2003). Although, the latter was interpreted as of possibly cheirolepidiaceaous affinity.

European araucariaceous fossil wood from the Cretaceous was described from the Albian of Hungary (Agathoxylon pannonicum (Greguss) Barale, BarbackA 
et Marc Philippe (Barale et al. 2002)), and Santonian of Aachen, Belgium (Dammaroxylon aachenense J.J.F.MeIJER (Meijer 2000), Dadoxylon cf. subherzynicum J.SchultzeMotel (Gottwald 2000)).

The Cenozoic Araucariaceae are reported from the Northern Hemisphere as poorly preserved ovuliferous cones Araucarites pojarkovae KRASSILOV from the Palaeocene of Siberia (Krassilov 1976), but this fossil was later reinterpreted by Golovneva (2006) and Krassilov and Kodrul (2006) as a fragment of an angiosperm. However, there are more definite fossils of Araucariaceae as fossil woods, Araucarioxylon shandongense U.PRAKASH et N.Z.Du from the middle Miocene deposits of the Shandong province in China (Prakash et al. 1995), and Agathoxylon sp. from the late Oligocene to early Miocene of the Qiutangling Formation of Ledong, Hainan Island, China (Feng et al. 2015).

Since the first publication of $A$. fricii by Bayer (1893) from the mid-Coniacian of Březno (Březno Formation), there has been no other report of the species or the genus within the Bohemian Cretaceous Basin. This situation makes the newly found specimen of great interest, and it also extends the first occurrence of $A$. fricii from the early/ middle Coniacian back to the early Coniacian and adds more diversity to the taxon.

\section{Material and methods}

The newly described cone scale complex is impressed in marine sandy marlstone from the Teplice Formation of the Bohemian Cretaceous Basin, as defined by Čech et al. (1980, Čech 2011). The age of the Teplice Formation, late Turonian to early Coniacian, is based on biostratigraphic, sequence stratigraphic and carbon isotope data (Wiese et al. 2004). It is generally quite a complicated formation, however in Radovesice the strata from which the Araucaria cone scale complex comes are assigned to the early Coniacian based on the index fossil belemnite Goniocamax lundgreni (Košt’ák et al. 2004). The holotype of Araucaria fricii is partly limonitised and impressed in marine marlstone from Březno locality, the Březno Formation of the Bohemian Cretaceous Basin. The type of sediment in which the fossil is impressed indicates gastropod layers of the Březno Formation that could be assigned to middle/early Coniacian age (Košt'ák oral communication).

Both specimens were photographed under low angle light with a Canon EOS 6D Camera equipped with a $24 \mathrm{~mm}$ Sigma lens. The holotype was collected in 1864 by H. Mayer, a teacher from Březno. The newly described specimen was collected in 1997 by Zdeněk Dvořák from the company Severočeské doly a.s.

\section{Systematic palaeobotany}

\section{Family Araucariaceae Henkel et W.Hochst., 1865 nom. cons.}

\section{Genus Araucaria Juss., 1789}

Ty p e. Araucaria araucana (Molina) K.Koch, 1873.

Remarks. The genus Araucaria has an extended fossil record (e.g., Stockey 1994). Its typical feature is the unique deltoid cone scale complex with a single centrally placed seed complemented by a ligula. All these features are clearly visible in the newly described specimen.

\section{Araucaria fricii Velen. ex E.BAYer, 1893 Text-fig. 1a, b}

1893 Araucaria fricii Velen. ex E.BAYER, p. 3, fig. 1.

1893 Araucaria fricii Velen. ex E.BAYer; Bayer in Frič, p. 128, fig. 177.

1894 Araucaria fricii Velen. ex E.BAYeR; Bayer in Frič, p. 124, fig. 177.

2007b Araucaria fricii Velen. ex E.BAYER; Kunzmann, p. 109, text-fig. 2a-c, pl. 1, figs 1-4.

2018 Araucaria fricii Velen. ex E.BAYER; Halamski et al., p. 126, pl. 2, figs 1-3.

Holotype. NM-F 1898, coll. National Museum, Prague, leg. H. Mayer in 1864 (Text-fig. 1a).

Type locality. Březno, the Czech Republic.

Type horizon. Březno Formation, middle/early Coniacian, Late Cretaceous.

Emended diagnosis. Ovuliferous cone scale complex cuneate, length greater than width, laterally narrow-winged, having one seed per cone scale complex. Ligula $2 / 3$ to $1 / 1$ of the length of the seed. Seed oval, oblong-oval to oblong-ovate. In cross-section wide oval to rhomboid, considerably narrower and shorter than the cone scale (emended from Kunzmann 2007b).

O the r materia 1. NM-F 5010, coll. National Museum, Prague, leg. Z. Dvořák 1997 (Text-fig. 1b); No. 451, coll. Knoll.

O the r o c c urrences. Radovesice near Kučlín, the Czech Republic (Teplice Formation, early Coniacian, Late Cretaceous); Hauset near Aachen, Belgium (late Santonian, Late Cretaceous; Kunzmann 2007b).

Description. The holotype (Text-fig. 1a) is a laterally narrow cuneate ovuliferous cone scale complex $15 \mathrm{~mm}$ wide $\times 29 \mathrm{~mm}$ long. It shows a centrally placed oval oblong seed $16 \mathrm{~mm} \times 6 \mathrm{~mm}$. A fragment of ligula is $8 \mathrm{~mm}$ wide. The apical part of the cone scale complex exhibits a terminal projection $6 \mathrm{~mm}$ wide $\times 7.5 \mathrm{~mm}$ long. The cone scale complex is partly limonitised, showing resin fragments imitating resin canals in the apical and central parts, some of irregular shape, always less the $0.2 \mathrm{~mm}$ in diameter.

The newly found specimen, No. NM-F 5010, (Text-fig. $1 b)$ is an impression in sandy marlstone from the Teplice Formation. It shows a deltoid cone scale complex, $20 \mathrm{~mm}$ wide $\times 27 \mathrm{~mm}$ long. The terminal projection is $7 \mathrm{~mm}$ wide $\times$ $5 \mathrm{~mm}$ long. The centrally placed seed impression is an elongate ovoid $15 \mathrm{~mm} \times 5 \mathrm{~mm}$. The ligula impression is $9 \mathrm{~mm}$ wide.

\section{Discussion}

The present emendation of the species diagnosis follows a more conservative approach than Kunzmann (2007b). He used a complete ovuliferous cone for his emendation, from the Santonian locality in Belgium. Although the Santonian material is more complete, it is from a different stratigraphic 

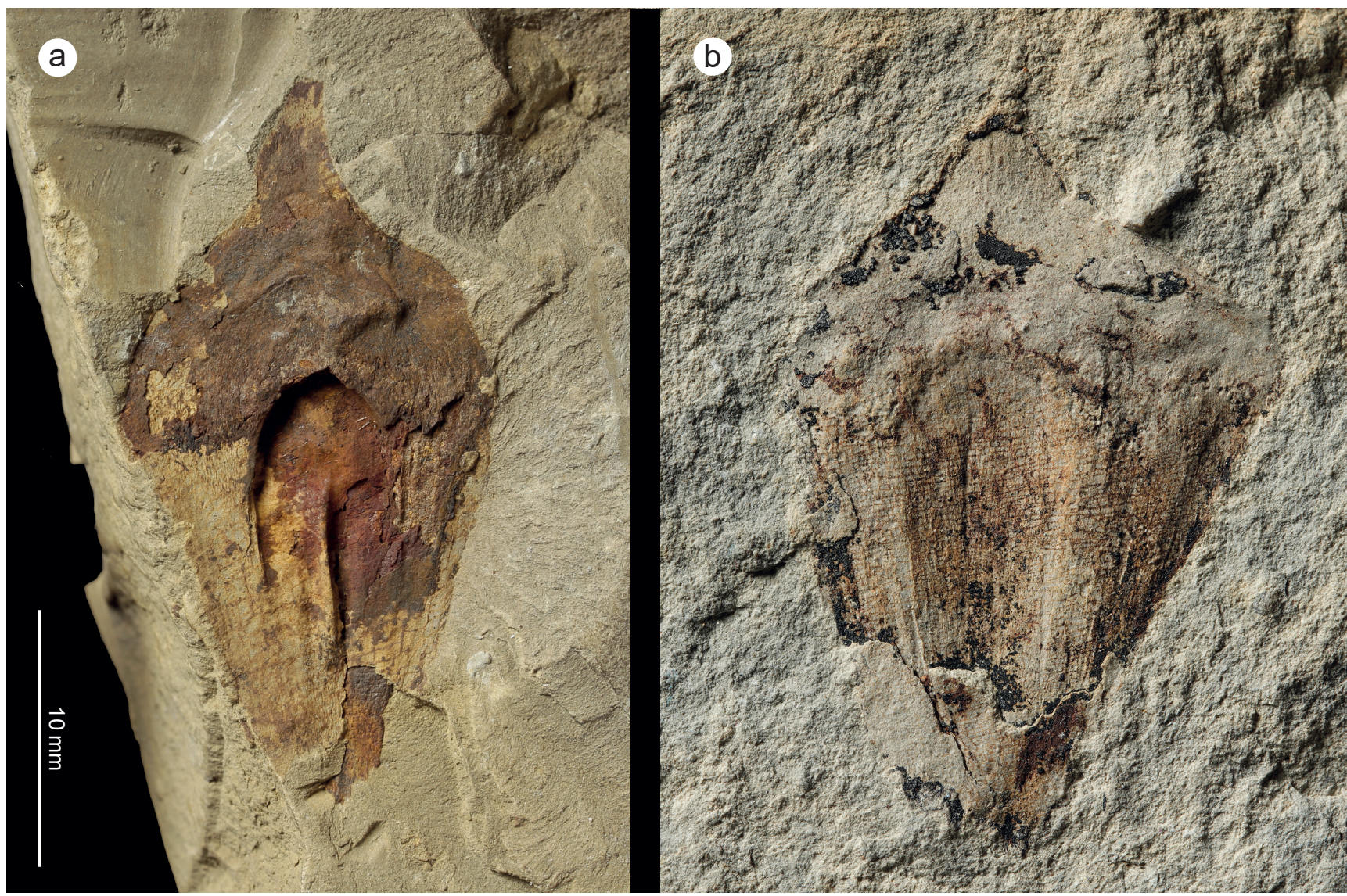

Text-fig. 1. Araucaria fricii Velen. ex E.BAYER. a: Holotype, Březno, early/middle Coniacian, No. NM-F 1898; b: Radovesice, early Coniacian, No. NM-F 5010. Equal in scale.

horizon, a different locality, and is in a different state of preservation. To avoid confusion, the author prefers having the emendation based only on the type material from the type horizon.

The studied cone scale complex A. fricii from the early Coniacian is broader than the holotype and does not show the long apical projection. However, as is known from recent ovuliferous cone scale complexes of various modern species of Araucaria, shapes and sizes of cone scale complex can vary remarkably, even within a single cone. This is why the shape and size of the newly described specimen are judged to fall within the accepted variability of $A$. fricii.

A. fricii was compared to other similar species by Kunzmann (2007b), in particular to Araucaria carolae L.KunZmAnN, from which it differs in having larger cone scale complexes and smaller seeds. A. fricii is similar to Aachenia debeyi Erw.KNOBLOCH (Knobloch 1972) in having a terminal projection and deltoid shape, but this similarity is only superficial; it differs from $A$. debeyi in having a single centrally placed seed. The type material of $A$. debeyi does not exhibit any seeds, therefore it cannot even be definitively assigned to the Araucariaceae (Kunzmann 2007a). A. fricii is similar to Araucaria sp. from the Maastrichtian of the Netherlands (van der Ham et al. 2010) in size and shape but differs from it in having a well-pronounced terminal projection.

Considering extant species of Araucaria, A. fricii is similar to species belonging to the section Eutacta. It shares a similar conspicuous apical projection with $A$. biramulata J.Buchiolz, A. muelleri (CArrière) Brongn. et Gris,
A. luxurians (Brongn. et Gris) de Laub., A. rulei F.Muell. ex LindL. and A. subulata VIEILL. (Kunzmann 2007b).

\section{Remarks}

Both specimens of the A. fricii cone scale complex known from the Bohemian Cretaceous Basin, also the discussed material from Belgium, and Araucaria sp. from the Maastrichtian of the Netherlands come from marine sediments.

The strictly marine taphonomy of the specimens might be due to the fact that Araucaria fricii and possibly other European Cretaceous araucarias grew in environments far from terrestrial sedimentary basins. This hypothesis is supported by the predominantly mesophytic character of extant Araucaria. It could therefore not have been preserved in the fresh-water sediments of the Klikov Formation from the South Bohemian Cretaceous Basins, although that formation is of Late Turonian to Santonian age (Knobloch 1985).

The species might have been relatively scarce because Arancaria was already a rare taxon in the Late Cretaceous, facing strong competition from angiosperms (Kunzmann 2007a, b).

\section{Acknowledgements}

I am particularly grateful to Zdeněk Dvořák from Severočeské doly a.s. for donation of the specimen, to 
Martin Košt'ák and Jakub Sakala for their discussion on the Coniacian stratigraphy of the Bohemian Cretaceous Basin. I am also thankful to Lenka Váchová (National Museum, Prague, the Czech Republic) for photography of the studied material and Petr Daneš for English editing. This research was supported by the Czech Ministry of Culture (IP DKRVO 2019-2023 2.II.c, National Museum, 00023272). My greatest thanks go to the two reviewers, Johanna Van Konijnenburg-van Cittert and Raymond van der Ham for their invaluable comments.

\section{References}

Barale, G. (1989): Sur trois nouvelles espèces de coniférales du crétacé inférieur d'Espagne: Intérêts paléoécologiques et stratigraphiques. - Review of Palaeobotany and Palynology, 61: 303-318. https://doi.org/10.1016/0034-6667(89)90036-5

Barale, G. (1992): De nouveaux restes fossiles attribués aux Araucariacées dans les calcaires lithographiques du Crétacé inférieur du Montsec (province de Lérida, Espagne). - Review of Palaeobotany and Palynology, 75 (1-2): 53-64. https://doi.org/10.1016/0034-6667(92)90149-B

Barale, G., Barbacka, M., Philippe, M. (2002): Early Cretaceous flora of Hungary and its palaeoecological significance. - Acta Palaeobotanica, 42: 13-27.

Bayer, E. (1893): O rostlinstvu vrstev březenských / Die Flora der Priesener Schichten. - preprint from Věstník Královské české společnosti nauk, třída mathematicko-prŕrodovědná, 1893(art. XXXIX): 1-50. (in Czech with German summary)

Bosma, H. F., van Konijnenburg-van Cittert, J. H. A., van Amerom, H. W. J., Hartkopf-Fröder, C. (2009): Conifers from the Santonian of Limburg, The Netherlands. - Cretaceous Research, 30(2): 483-495. https://doi.org/10.1016/j.cretres.2008.09.007

Čech, S. (2011): Palaeogeography and stratigraphy of the Bohemian Cretaceous Basin (Czech Republic) - an overview. - Geologické výzkumy na Moravě a ve Slezs$\mathrm{ku}, 18(1): 18-21$.

Čech, S., Klein, V., Kř́žž, J., Valečka, J. (1980): Revision of the Upper Cretaceous stratigraphy of the Bohemian Cretaceous Basin. - Věstník Ústředního ústavu geologického, 55(5): 277-296.

Feng, X.-X., Oskolski, A. A., Liu, X.-Y., Liao, W.-B., Jin, J.-H. (2015): A new record of Agathoxylon from the Tertiary of South China. - IAWA Journal, 36(3): 338-344. https://doi.org/10.1163/22941932-20150104

Frič, A. (1893): Studien im Gebiete der böhmischen Kreideformation. Paläontologische Untersuchungen der einzelnen Schichten. V. Die Priesener Schichten. - Archiv der naturwissenschaftliche Landesdurchforschung von Böhmen, 9(1): 1-135.

Frič, A. (1894): Studie v oboru kř́ídového útvaru v Čechách. Paleontologické prozkoumání jednotlivých vrstev. V. Březenské vrstvy. [Treatise of Cretaceous System, Palaeontological exploration of individual strata. V. Březno Member]- Archiv pro př́rodovědecké proskoumání Čech, 9(1): 1-129.
Golovneva, L. B. (2006): Alasia gen. nov muzhskie sotsvetia svyazannye s listyam Trochodendroides (Cercidiphyllaceae) [Alasia, gen. nov. - male inflorescences, associated with Trochodendroides leaves (Cercidiphyllaceae)]. - Botanicheskiy Zhurnal, 91: 1889-1906. (in Russian)

Gottwald, H. (2000): Gymnosperme und dicotyle Hölzer (61) aus den "Aachener Sanden" der Oberen Kreide von NO Belgien und NW-Deutschland. - Documenta naturae, 131: 1-65.

Halamski, A. T., Kvaček, J., Svobodová, M. (2018): Fossil mega- and microflora from the Březno Beds s.s. (Bohemian Cretaceous Basin, Coniacian). - Review of Palaeobotany and Palynology, 253: 123-138. https://doi.org/10.1016/j.revpalbo.2018.03.002

Hébert, M. (1869): Recherches sur l'âge des grès à combustibles d'Höganäs et des grès à végétaux de Hör (Suède méridionale). - Annales des sciences géologiques, Sér. 2, 27: 117-496.

van der Ham, R. W. J. M. (2004): Een kegelschub van een Slangenden (Araucaria) uit de ENCI [A conical scale of a snake pine (Araucaria) from ENCI]. - Sprekende Bodem, 48: 97-99. (in Dutch)

van der Ham, R. W. J. M., Jagt, J. W. M., Renkens, S., van Konijnenburg-van Cittert, J. H. A. (2010): Seed-cone scales from the upper Maastrichtian document the last occurrence in Europe of the Southern Hemisphere conifer family Araucariaceae. - Palaeogeography, Palaeoclimatology, Palaeoecology, 291: 469-473. https://doi.org/10.1016/j.palaeo.2010.03.017

van der Ham, R. W. J. M., van Konijnenburg-van Cittert, J. H. A., Dortangs, R. W., Herngreen, G. F. W., van der Burgh, J. (2003): Brachyphyllum patens (Miquel) comb. nov. (Cheirolepidiaceae?): Remarkable conifer foliage from the Maastrichtian type area (Late Cretaceous, NE Belgium, SE Netherlands). - Review of Palaeobotany and Palynology, 127: 77-97. https://doi.org/10.1016/S0034-6667(03)00095-2

Heer, O. (1881): Contributions à la flore fossile du Portugal. - Imprimerie de l'Académie Royale des Sciences, Lisbonne, $51 \mathrm{pp}$. https://doi.org/10.5962/bhl.title.78053

Henkel, J. B., Hochsteter, W. (1865): Synopsis der Nadelhölzer, deren charakteristischen Merkmale nebst Andeutungen über ihre Cultur und Ausdauer in Deutschlands Klima. - J. G. Cottasche Buchhandlung, Stuttgart, 446 pp. https://doi.org/10.5962/bhl.title.15349

Jussieu, A. L. de (1789): Genera plantarum secundum ordines naturales disposita, juxta methodum in Horto Regio Parisiensi exaratam. - Apud Viduam Herissant et Theophilum Barrois, Parisii, 498 pp. https://doi.org/10.5962/bhl.title.284

Koch, K. (1873): Dendrologie. Bäume, Sträucher und Halbsträucher, welche in Mittel- und Nord- Europa im Freien kultivirt warden, 2. Theil, 2. Abth. - Ferdinand Enke, Erlangen, 424 pp.

Košt'ák, M., Čech, S., Ekrt, B., Mazuch, M., Wiese, F., Voight, S., Wood, C. J. (2004): Belemnites of the Bohemian Cretaceous Basin in a global context. - Acta Geologica Polonica, 54(4): 511-533. 
Knobloch, E. (1972): Aachenia debeyi n. g. n. sp. - eine neue Konifere aus dem Senon von Aachen. - Neues Jahrbuch für Geologie und Paläontologie, Monatshefte, 1972(7): 400-406.

Knobloch, E. (1985): Paläobotanisch-biostratigraphische Charakteristik der Klikov-Schichtenfolge (OberturonSanton) in Südböhmen. - Sborník geologických věd, Geologie, 40: 101-145.

Krassilov, V. A. (1976): Tsagayanskaya flora Amurskoy oblasti [Tsagajan flora of the Amur province]. - Nauka, Leningrad, 92 pp. (in Russian)

Krassilov, V. A., Kodrul, T. M. (2006): In situ pollen of Alasia, a supposed staminate inflorescence of Trochodendroides plant. - Acta Musei Nationalis Pragae, Series B - Historia Naturalis, 64: 115-124.

Kräusel, R. (1922): Beiträge zur Kenntnis der Kreideflora, I. Über einige Kreidepflanzen von Swalmen (Niederlande). - Mededelingen - Rijks Geologische Dienst, Ser. A, 2: 1-40.

Kunzmann, L. (2007a): Araucariaceae (Pinopsida): Aspects in palaeobiogeography and palaeobiodiversity in the Mesozoic. - Zoologischer Anzeiger, 246: 257-277. https://doi.org/10.1016/j.jcz.2007.08.001

Kunzmann, L. (2007b): Neue Untersuchungen zu Araucaria Jussieu aus der europäischen Kreide. - Palaeontographica, Abt. B, 276: 97-131. https://doi.org/10.1127/palb/276/2007/97

Kvaček, J. (2000): Frenelopsis alata and its microsporangiate and ovuliferous reproductive structures from the Cenomanian of Bohemia (Czech Republic, Central Europe). - Review of Palaeobotany and Palynology, 112: 51-78. https://doi.org/10.1016/S0034-6667(00)00035-X

Kvaček, J. (2007): The conifer Brachyphyllum squamosum from the Bohemian Cenomanian. - Acta Palaeobotanica, 47(1): 25-35.

Kvaček, J., Barrón, E., Heřmanová, Z., Mendes, M. M., Karch, J., Žemlička, J., Dudák, J. (2018): Araucarian conifer from late Albian amber of northern Spain. - Papers in Palaeontology, 4: 643-656. https://doi.org/10.1002/spp2.1223

Kvaček, J., Mendes, M. M. (2020): Callialastrobus sousai gen. et sp. nov., a new araucariaceous pollen cone from the Early Cretaceous of Catefica (Lusitanian Basin, western Portugal) bearing Callialasporites and Araucariacites pollen. - Review of Palaeobotany and Palynology, 283: 104313 (9 pp.).

https://doi.org/10.1016/j.revpalbo.2020.104313

Kvaček, J., Yilmaz, I. O., Hoşgör, I., Mendes, M. M. (2019): New araucarian conifer from the Late Cretaceous (Campanian-Maastrichtian) of Southeastern Turkey. - International Journal of Plant Sciences, 180: 597-606. https://doi.org/10.1086/703525

Meijer, J. J. F. (2000): Fossil wood from the Late Cretaceous Aachen Formation. - Review of Palaeobotany and Palynology, 112: 297-336. https://doi.org/10.1016/S0034-6667(00)00007-5

Němejc, F., Kvaček, Z. (1975): Senonian plant macrofossils from the region of Zliv and Hluboká (near České Budějovice) in South Bohemia. - Universita Karlova, Praha, $82 \mathrm{pp}$.

Oskolski, A. A. (2015): Cenozoic Araucariaceae in the Northern Hemisphere: decline and recovery. - Wulfenia, 22: $261-264$.

Prakash, U., Du, N. Z., Tripathi, P. P. (1995): Fossil woods from the Miocene sediments of China with remarks on environmental implications of Miocene floras of the region. - In: Pant, D. D. (ed.), Global environment and diversification of plants through geological time. South Asian Publishers, Allahabad, pp. 341-360.

Saporta, G. de (1894): Flore fossile du Portugal. Nouvelles contributions à la flore Mésozoique. - Imprimerie de l'Académie Royale des Sciences, Lisbonne, 286 pp. https://doi.org/10.5962/bhl.title.149948

Stockey, R. A. (1994): Mesozoic Araucariaceae: morphology and systematic relationships. - Journal of Plant Research, 107: 493-502. https://doi.org/10.1007/BF02344070

Wiese, F., Čech, S., Ekrt, B., Košt’ák, M., Mazuch, M., Voigt, S. (2004): The Upper Turonian of the Bohemian Cretaceous Basin (Czech Republic) exemplified by the Úpohlavy working quarry: integrated stratigraphy and palaeoceanography of a gateway to the Tethys. - Cretaceous Research, 25: 329-352.

https://doi.org/10.1016/j.cretres.2004.01.003 